\title{
Геологический институт КНЦ РАН в исследованиях металлогении кристаллических щитов; фундаментальные проблемы и перспективы изучения месторождений полезных ископаемых Кольского региона
}

\author{
Зозуля Д.Р., Жиров Д.В., Рундквист Т.В., Козлов Н.Е. \\ Геологический институт КНЦ РАН, Anamumbl, geoksc@geoksc.apatity.ru
}

Аннотация. В работе обобщены достижения и результаты многолетних исследований сотрудников Геологического института КНЦ РАН в области металлогении и геологии месторождений полезных ископаемых Фенноскандинавского щита. Обоснованы основные цели и задачи Института по этому направлению на кратко-среднесрочную перспективу с учетом вызовов современного отечественного и мирового рынка, а также необходимости воспроизводства и диверсификации минерально-сырьевой базы Кольского региона. Приведен краткий обзор подготовленных к освоению месторождений полезных ископаемых и новых для региона видов минерального сырья. Раскрываются основные фундаментальные проблемы металлогении, связанные с региональной спецификой.

Ключевые слова: металлогения, полезные ископаемые, перспективы, Кольский регион.

\section{Geological Institute KSC RAS in metallogeny studies of crystalline shields; fundamental problems and prospects for the study of mineral deposits of the Kola region}

\author{
Zozulya D.R., Zhirov D.V., Rundkvist T.V., Kozlov N.E. \\ Geological Institute KSC RAS, Apatity,geoksc@geoksc.apatity.ru
}

\begin{abstract}
The paper summarizes the achievements and results of long-term studies of the staff of the Geological Institute KSC RAS in metallogeny and geology of mineral deposits of the Fennoscandian Shield. The main goals and objectives of the Institute in this area for the short-medium periods are substantiated taking into account the challenges of the modern domestic and world market and the need to renew and diversify the mineral resource base of the Kola region. A brief review of mineral deposits prepared for the exploitation and new types of mineral raw materials for the region is given. The basic fundamental problems of metallogeny, connected with the regional specificity, are revealed.

Key words: metallogeny, ore deposits, perspectives, Kola region.
\end{abstract}

Начиная с 20-х гг. ХХ века, с первыХ экспедиций АН СССР и Комиссии по естественным производительным силам под руководством А.Е. Ферсмана, открытие практического большинства рудных узлов и месторождений было связано с сотрудниками Геологического института (базы Тиетта) (рис. 1). Научно-методическое сопровождение в части минералогии, петрологии, тектоники и металлогении проводилось в ходе поисковых и геологоразведочных работ на протяжении всего XX века и продолжается в XXI. На подготовленной сырьевой базе построен и успешно функционирует уже более 80 лет один из крупнейших в России горнопромышленных комплексов по добыче апатита, железной и медно-никелевой руды, слюд, редких металлов и др. (Геология ..., 2002).

В настоящее время исследования ГИ КНЦ РАН развиваются в нескольких направлениях, так или иначе связанных с сырьевой базой Кольского региона:

1. Изучение процессов генезиса месторождений полезных ископаемых с использованием новейших прецизионных методов изучения минерального сырья, включая минералогические, изотопно-геохимические и геохронологические методы. Работы проводятся на базе Кольского центра коллективного пользования геохронологических и изотопно-геохимических исследований.

2. Исследование традиционных для региона месторождений минерального сырья, разрабатываемых на действующих горнорудных предприятиях (медно-никелевые, железорудные и апатитовые месторождения). Работы направлены на повышение эффективности и безопасности эксплуатации данных месторождений, а также вовлечение в промышленное освоение запасов, залегающих в трудных горнотехнических условиях. 
3. Поиск и изучение новых для региона месторождений и рудопроявлений полезных ископаемых. Сюда относятся те виды сырья, которые в настоящее время не разрабатываются горнопромышленными предприятиями Мурманской области. В первую очередь это месторождения платины и палладия (Федоровотундровское, Вуручуайвенч, Киевей, Северный Каменник), Колмозерское месторождение лития, небольшие месторождения общераспространенного сырья (торф, диатомит, гуматы), Сахарйокское месторождение циркония, иттрия и редких земель и многие другие перспективные объекты.

4. Обоснование поисковых направлений на перспективные и нетрадиционные для региона высоколиквидные виды полезных ископаемых: золото, алмазы, углеводородное сырье.

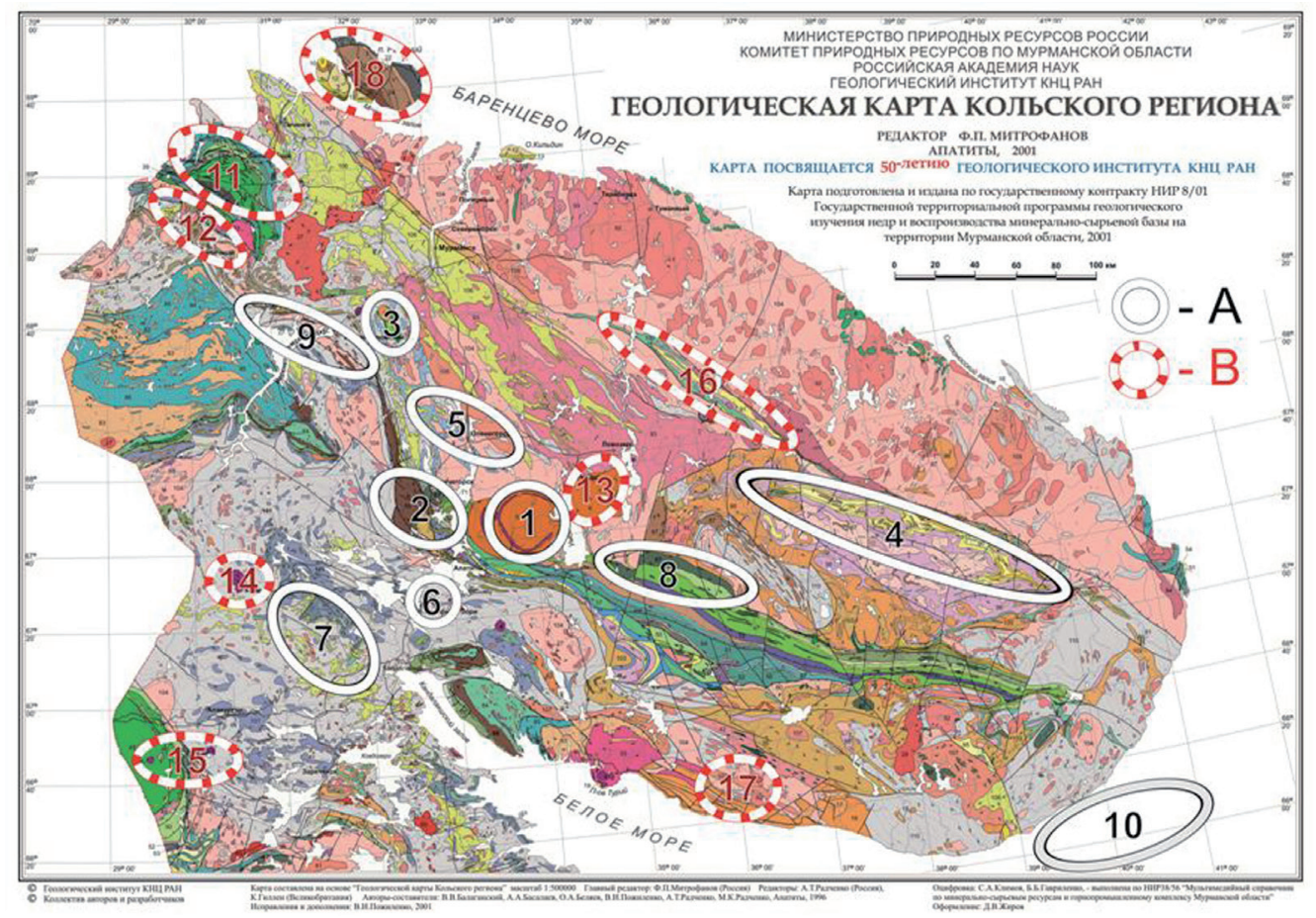

Рис. 1. Вклад и участие сотрудников ГИ КНЦ РАН в открытие и подготовку минерально-сырьевой базы Колького региона (с дополнениями на основе (Геологическая ..., 2001)).

А - месторождения и рудные узлы открыты сотрудниками; 1 - группа Хибинских апатит-нефелиновых и редкометалльных месторождений (А.Е. Ферсман, Б.М. Куплетский, А.Н. Лабунцов и др.); 2 - Мончегорские медно-никелевые месторождения (А.Е. Ферсман, Н.Н. Гуткова, И. Кикоин и др.); 3 - массив Гремяха-Вырмес с титаномагнетит-ильменитовым оруденением (А.А. Полканов); 4 - Кейвская группа киантитовых месторождений (А.А. Григорьев и др.); 5 - магнетитовые кварциты оленегорской группы (О.А. Воробьева и др.); 6 - месторождение перовскит-титаномагнетитовых руд (Б.М.Куплетский и др.); 7 - слюдоносные пегматиты (Куплетский и др.); 8 - месторождения МПГ (Ф.П. Митрофанов, А.У. Корчагин и др.); 9 - графитоносная зона (А.А. Жамалетдинов и др.); 10 - потенциально алмазоносная зона галечников в Горле Белого моря (Ф.П. Митрофанов, Б.В. Гавриленко и др.).

В - месторождения и рудные узлы, открытие и изучение которых проходило с активным участием сотрудников: 11 - Печенгское рудное поле (Cu-Ni); 12 - Аллареченское рудное поле (Cu-Ni); 13 - Ловозерские редкометалльные месторождения; 14 - Ковдосркие месторождения (апатит-магнетит-бадделеитовых руд, флогопита и вермикулита); 15 - месторождения массивов Вуориярви и Салланлатва (железо, апатит, слюды, барит, редкие металлы); 16 - Колмозеро-Вороньинский рудный узел (литий и др. редкие металлы, золото, молибден и др.); 17 - Терская площадь слабо алмазоносных кимберлитов; 18 - потенциально газо- и нефтеносная рифейская структура п-ов Средний и Рыбачий.

Fig. 1. Input and participation of GI KSC RAS' scientists in discovery and substantiation of mineral raw-material base of the Kola region. 
Главными фундаментальными направлениями исследований коллектива являются (1) геохронология основных металлогенических эпох и крупных минерагенических провинций (установление абсолютного времени происхождения, длительности и последовательности рудогенных процессов и событий) и (2) генезис конкретных месторождений Евро-Арктической зоны РФ (ЕАЗРФ).

К наиболее важным ранее полученным результатам следует отнести обоснование комплекса геолого-геофизических и изотопно-геохимических индикаторов продуктивности (фертильности) интракратонных раннепротерозойских расслоенных комплексов, что в свою очередь привело к прогнозному обоснованию и последующему открытию Кольской платинометалльной провинции (КПП), включающую два крупных рудных узла (Федорово-Панский и Мончегорский) и десятки интрузивов с ресурсным потенциалом более 2000 т палладиевого эквивалента (Митрофанов и др., 1999; Mitrofanov et al., 2013). Другим научным открытием стало установление и показ на примере расслоенных массивов КПП полихронности и длительности формирования интрузивных комплексов (Баянова и др., 2010, 2017; Bayanova et al., 2014). Это особенно важно в связи с возможностью фильтрации рудных фаз от безрудных. Выполняются опережающие технологические исследования по совершенствованию методов извлечения $\mathrm{Au}, \mathrm{Ag}$ и ЭПГ из различных типов руд и отходов. Многочисленные результаты по геохронологическому и платино-палладиевому направлениям опубликованы в сотнях статей и монографий, сведены в десятках научных и геологических отчётах, стали основой нескольких десятков диссертационных работ.

Другими первоочередными объектами исследований стали группа апатит-нефелиновых месторождений Хибин и Ковдорское месторождение апатитовых и железных руд. Здесь имеются большие наработки по технологиям прогноза и управления геодинамическими (сейсмодинамическими) рисками при разработке глубоких горизонтов в осложнённых горнотехнических условиях (Жиров и др., 2016 и др.). Новаторскими решениями являются наши методики и аппаратные комплексы для дистанционного сбора больших объёмов пространственно-распределённых геолого-структурных данных и оригинальное программное обеспечение по дополнению фотореалистических моделей различными объектами геолого-структурного содержания (Козырев, Жиров и др., 2018). Реализация этих наработок позволит значительно пролонгировать сроки эксплуатации месторождений региона.

Впервые на современном уровне проведены минералого-геохимические (Морозова, 2018) и геохронологические (Кудряшов и др., 2015) исследования редкометальных пегматитов одной из крупнейших в мире группы месторождений Li, Cs и Та в зоне Колмозеро-Воронья.

Сотрудниками коллектива обоснована древнейшая в мире редкометальная (REE, Y, Zr) металлогеническая эпоха, связанная с позднеархейскими щелочными породами (Митрофанов и др., 2000; Зозуля и др., 2012), выделены перспективные площади алмазоносного кимберлитового магматизма и районы возможного накопления россыпных алмазов в современных прибрежно-морских и аллювиальных отложениях (Zozulya et al., 2009).

Заделы по углеводородному сырью базируются на огромной базе фактографических данных, накопленных при бурении рифейских отложений на п-вах Средний и Рыбачий, а также на геодинамических реконструкциях баренцевоморского шельфа и континентальной окраины (Сорохтин и др., 2015).

Главная цель исследований ГИ КНЦ РАН на кратко- и среднесрочную перспективу - выполнить комплекс геологических, структурных, минерагенических, петрологических и геохронологических исследований по конкретным перспективным направлениям и минерально-сырьевым объектам в Евро-Арктической зоне Российской Федерации (ЕАЗРФ) и для обоснования их геологопромышленной и социально-экономической эффективности и значимости.

Основные цели и задачи научных исследований на среднесрочный горизонт планирования группируются в следующие разделы:

- геохронология основных металлогенических эпох и крупных изверженных провинций ЕАЗРФ с акцентом на: новые месторождения и проявления Кольской платинометалльной провинции (палеопротерозойская провинция), золоторудные проявления в палеопротерозойских и архей- 
ских поясах Карело-Кольского региона, месторождения палеозойских щелочно-ультраосновных с карбонатитами интрузий (палеозойская провинция);

- комплексное петролого-геохимическое, изотопно-геохрологическое, геологическое и минерагеническое изучение руд и вмещающих пород новых месторождений и проявлений $\mathrm{Pd}, \mathrm{Pt}, \mathrm{Cu}$, $\mathrm{Ni}, \mathrm{Cr}$ Мончегорского рудного узла (пласт Габбро-10, Сопчеозерское, риф Сопча-пласт 330 и др.) и Федорово-Панского интрузивного комплекса (Федоровотундровское, Северный Каменник и Киевей, участки Южного рифа);

- изучение вещественного и минерального состава, геохронологии, рудообразующих процессов и петрологии, рудоконтролирующих факторов и технологических свойств руд литий-цезиевых месторождений зоны Колмозеро-Воронья;

- геолого-геохимическое и минералогическое изучение редкометальных (Y, REE, $\mathrm{Nb}, \mathrm{Ta}, \mathrm{Zr}$, $\mathrm{Th}, \mathrm{U}, \mathrm{Hf}, \mathrm{Ba}, \mathrm{Sr}, \mathrm{Be})$ месторождений и проявлений, связанных с разновозрастными карбонатитами и щелочными породами Кольского региона (массивы Хибины, Ловозеро, Вуориярви, Салланлатва, Кейвская щелочная провинция);

- геолого-геохимическое, структурное и минерагеническое изучение палеопротерозойских золотоносносных сутурных зон (Лапландско-Кольский ороген: Лапландский гранулитовый пояс и палеорифт Печенга-Имандра-Варзуга);

- изучение процессов перераспределения и накопления рассеянных элементов ( $\mathrm{Sc}, \mathrm{V}, \mathrm{Cr}, \mathrm{Mo}$, $\mathrm{Se}, \mathrm{Te}, \mathrm{W}$ и др.) и их минералогии в рудопроявлениях Печенга-Имандра-Варзугской палеорифтовой зоны;

- реконструкция эволюции осадочных бассейнов западной части Российской Арктики и прогнозное обоснование площадей нефтегазоносности;

- 3D моделирование структур рудных полей и рудных тел конкретных месторождений для обоснования прироста запасов по флангам и на глубину, а также поиска новых слепых залежей;

- 3D моделирование в целях обеспечения безопасного освоения запасов глубоких и сверхглубоких горизонтов эксплуатирующихся месторождений стратегических видов сырья.

Главными результатами таких мультидисциплинарных исследований будут определение механизмов формирования и особенностей эволюции рудно-магматических систем, выявление механизмов происхождения рудных залежей и благоприятных структур для локализации месторождений полезных ископаемых. Один из конечных результатов исследования - обоснование перспективных участков недр Кольского региона на обнаружение новых месторождений и рудопроявлений. В отношении традиционных для Мурманской области полезных ископаемых исследования будут сконцентрированы на аспектах рационального и полного извлечения запасов уникальных месторождений апатита, железных и медно-никелевых руд, а также повышения комплексности использования сырья за счёт увеличения перечня извлекаемых полезных компонентов и выпускаемых промышленных продуктов.

Несомненным является и фундаментальная значимость проводимых ГИ КНЦ РАН исследований. Выявление особенностей генезиса рудных месторождений является главным условием для постановки геологоразведочных работ, прироста запасов по их результатам и комплексного использования сырья на разрабатываемых объектах, а так же является важнейшим критерием для прогнозирования и открытия новых месторождений. К другим важным фундаментальным проблемам в области изучения металлогении региона можно отнести следующее: высокая степень дифференциации вещества с масштабным накоплением литофильных элементов в раннем докембрии (формирование крупных Li месторождений); обогащенные мантийные источники в раннем докембрии и плейт-тектоника в архее; процессы образования кислых сиаллитных кор выветривания в раннем докембрии (Кейвский сланцевый комплекс); возникновение разных типов мантийных источников для рудоносных (Cu-Ni-PGE) магматических пород; полигенное (магматогенное и метаморфогенное) и длительное формирование редкометальных руд (Кейвская щелочная провинция); механизмы формирования суперкрупных месторождений полезных ископаемых. 
Tрадиционные для региона месторождения минерального сырья, разрабатываемые на действующих горнорудных предприятиях (медно-никелевые, железорудные и апатитовые месторождения) имеют громадное значение для социально-экономического развития региона и для страны в целом. Здесь добывается 100\% фосфатного сырья и циркония, около 13\% никеля, около 10\% железных руд, а также значительные объёмы керамических пегматитов, строительных материалов (щебень, глины, облицовочный камень) и др. Прямой вклад горнопромышленной отрасли в валовый региональный продукт (ВРП) оценивается около $22 \%$, а если учесть загрузку и мультипликативный эффект по смежным отраслям и видам деятельности, то в совокупности эта роль возрастёт не менее, чем до 40\% (Козлов, Жиров, 2018). Таким образом, значение минерально-сырьевого комплекса для социально-экономического положения и развития северо-западного форпоста РФ безальтернативно. К сожалению, после 60-80 лет эксплуатации запасы основных месторождений традиционных полезных ископаемых истощены, а горнотехнические условия сильно ухудшены.

Наиболее эффективными путями решения этой проблемы служат: - максимальная пролонгация срока службы инфраструктуры ГОК-ов и эксплуатируемых крупных месторождений; - поиск и освоение традиционных сырьевых объектов в районах с развитой инфраструктурой; - геологопромышленное и социально-экономическое обоснование строительства крупных горнопромышленных центров на базе нетрадиционных для региона полезных ископаемых. Геолого-структурное моделирование Ковдорского и Хибинских месторождений позволит эффективно, безопасно, рационально и полно извлечь оставшиеся на глубоких горизонтах запасы руд, тем самым продлить эффективное социально-экономическое развитие моногородов от 10 до 40 лет.

Hoвые для региона месторождения и рудопроявления полезных ископаемых включают, в первую очередь, объекты, поставленные на государственный баланс. К ним относятся месторождения платины и палладия (Федоровотундровское, Вуручуайвенч, Киевей, Северный Каменник), Колмозерское и Полмостундровское месторождения лития, небольшие месторождения общераспространенного сырья (строительные камни, торф, диатомит), Сахарйокское месторождение циркония, иттрия и редких земель, месторождение титана Гремяха-Вырмес.

Перспективные минеральные ресурсы региона могут быть востребованы в краткой и среднесрочной перспективе и требуют достойного внимания и доизучения уже на сегодняшнем этапе. К ним относятся кианит, золото, алмазы, углеводородное сырье, эвдиалит, титаномагнетит, редкометальное сырье (REE, Zr), уран, торий, сырье для высокотехнологичного производства.

Работа выполнена в рамках темы НИР №0226-2019-0053.

\section{Литература}

1. Баянова Т.Б., Нерович Л.И., Митрофанов Ф.П., Серов П.А., Жавков В.А. Мончетундровский базитовый массив Кольского региона: новые геологические и изотопно-возрастные данные // Доклады РАН. Т. 431. № 2. 2010. C. 1-7.

2. Баянова Т.Б., Рундквист Т.В., Серов П.А., Корчагин А.У., Карпов С.М. Палеопротерозойский ФедоровоПанский расслоенный ЭПГ-комплекс северо-восточной части Арктического региона Балтийского щита: новые $\mathrm{U}-\mathrm{Pb}$ (по бадделеиту) и $\mathrm{Sm}-\mathrm{Nd}$ (по сульфидным минералам) данные // Доклады Академии наук. 2017. T. 472. № 1. C. 52-56.

3. Геология рудных районов Мурманской области. (под ред. Митрофанова Ф.П., Бичука Н.И.). Авторы: Пожиленко В.И., Гавриленко Б.В., Жиров Д.В., Жабин С.В. Апатиты: Изд. Кольского научного центра РАН. 2002. $359 \mathrm{c}$.

4. Геологическая карта Кольского региона масштаба 1:500000. Гл. ред. Ф.П. Митроофанов. (Авторы В.В. Балаганский, А.А. Басалаев, О.А. Беляев, В.И. Пожиленко, А.Т. Радченко, М.К. Радченко). Изд-е 2-е исправленное и дополненное. Апатиты. 2001.

5. Жиров Д.В., Мелихова Г.С., Рыбин В.В., Сохарев В.А., Климов С.А. Особенности инженерно-геологического изучения массивов скальных пород в целях проектирования глубоких карьеров на примере Ковдорского месторождения магнетитовых и апатитовых руд. Ч. 1. Вестник КНЦ РАН. 2016. № 1. С. 15-25.

6. Жиров Д.В., Мелихова Г.С., Рыбин В.В., Сохарев В.А., Климов С.А. Особенности инженерно-геологического изучения массивов скальных пород в целях проектирования глубоких карьеров на примере Ковдорского месторождения магнетитовых и апатитовых руд. Ч. 2. Вестник КНЦ РАН. 2016. № 2. С. 19-29. 
7. Жиров Д.В., Климов С.А., Пантелеев А.В., Жирова А.М. Выделение факторов контроля геодинамических опасностей на примере 3D геолого-структурной модели природно-технической системы «рудник Расвумчоррский - карьер Центральный» (Хибины). М.: ГИАБ. № 7. 2016. С. 200-227.

8. Зозуля Д.Р., Лялина Л.М., Иби Н., Савченко Е.Э. Геохимия руд, минералогия циркона и генезис иттрийциркониевого месторождения Сахарйок (Кольский полуостров, Россия) // Геология рудных месторождений. 2012. Т. 54. № 2. С. 99-118.

9. Козлов Н.Е., Жиров Д.В. Состояние и перспективы минерально-сырьевого комплекса Мурманской области // Аналитический Вестник Совета Федераций Федерального собрания Российской Федерации. 2018. № 20 (709). С. 75-82.

10. Козырев А.А., Жиров Д.В., Климов С.А., Семенова И.Э, Аветисян И.М., Савченко С.Н. 3D - моделирование структурных неоднородностей породных массивов центрального типа Фенноскандинавского кристаллического щита (Глава 7.) / Геомеханические поля и процессы: экспериментально-аналитические исследования формирования и развития очаговых зон катастрофических событий в горно-технических и природных системах / отв. ред. Н.Н. Мельников / Рос. акад. наук. Сиб. отд-ние. Ин-т горного дела. Новосибирск: Изд-во СО РАН. 2018. С. 162-203.

11. Кудряшов Н.М., Лялина Л.М., Апанасевич Е.А. Возраст редкометалльных пегматитов месторождения Васин-Мыльк (Кольский регион): результаты геохронологического $\mathrm{U}-\mathrm{Pb}$ - исследования микролита // ДАН. 2015. Т. 461. № 4. С. 437-441.

12. Митрофанов Ф.П. и др., Кольская платинометальная провинция: новые данные // Платина России. Кн. 1. Москва ЗАО «Геоинформмарк». 1999. С. 43-52.

13. Митрофанов Ф.П., Зозуля Д.Р., Баянова Т.Б., Левкович Н.В. Древнейший в мире анорогенный щелочногранитный магматизм в Кейвской структуре Балтийского щита // Доклады РАН. 2000. Т. 374. № 2. С. $238-241$.

14. Морозова Л.Н. Колмозерское литиевое месторождение редкометалльных пегматитов: новые данные по редкоэлементному составу (Кольский полуостров) // Литосфера. 2018. Т. 18. № 1. С. 82-98.

15. Сорохтин Н.О., Лобковский Л.И., Козлов Н.Е., Новиков Н.Г., Никифоров С.Л., Богданова О.Ю. Эволюция Баренцевоморского бассейна и потенциальная нефтегазоносность прибрежной зоны Кольского региона //Доклады академии наук. 2015. Т. 465. № 6. С. 711-714.

16. Bayanova T., Mitrofanov F., Serov P., Nerovich L., Yekimova N., Nitkina E. and Kamensky I. Layered PGE Paleoproterozoic (LIP) Intrusions in the N-E Part of the Fennoscandian Shield - Isotope Nd-Sr and 3He/4He Data, Summarizing U-Pb Ages (on Baddeleyite and Zircon), Sm-Nd Data (on Rock-Forming and Sulphide Minerals), Duration and Mineralization / Geochronology - Methods and Case Studies / Edited by Nils-Axel Mörner // INTECH. 2014. P. 143-193.

17. Mitrofanov F.P., Bayanova T.B., Korchagin A.U., Groshev N.Yu., Malitch K N., Zhirov D.V., and Mitrofanov A.F. East Scandinavian and Noril'sk Plume Mafic Large Igneous Provinces of Pd-Pt Ores: Geological and Metallogenic Comparison // Geology of Ore Deposits. 2013. V. 55. N. 5. P. 305-319.

18. Zozulya D.R., O’Brien H., Peltonen P., Lehtonen M. Thermobarometry of mantle-derived garnets and pyroxenes of Kola region (NW Russia): lithosphere composition, thermal regime and diamond prospectivity // Bulletin of the Geological Society of Finland. 2009. V. 81. P. 143-158. 